\title{
ПУБЛИЧНАЯ ВЛАСТЬ В КОНТЕКСТЕ ОСНОВНОГО ЗАКОНА
}

\section{PUBLIC AUTHORITY IN THE CONTEXT OF THE BASIC LAW}

A. Voronov

Summary: Based on the analysis of amendments to the Constitution of the Russian Federation initiated by the President of Russia, the author states that the term "public authority,» which differs significantly in content from the term «public authority,» received a legitimate sound; the question of the study and scientific justification of the organization and functioning of public authority in the Russian Federation, establishing its relationship with the legislative, executive and judicial branches of a single state power is very relevant.

The author summarizes that the primary basis of public power is the institutions of civil society, which are part of the concept of public power and are indigenous in it.

Keywords: amendments to the Constitution of the Russian Federation, state power, public power, civil society institutions.
Воронов Алексей Михайлович

Д.ю.н., профессор, г.н.С., Академия управления МВД России Alex_voronoff@mail.ru

Аннотация: На основе анализа поправок к Конституции Российской Федерации, инициированных Президентом России, автор констатирует, что легитимное звучание получил термин «публичная власть», отличающийся по содержанию от термина «государственная власть», при этом вопрос 06 исследовании и научном обосновании организации и функционирования публичной власти в Российской Федерации, установлении ее соотношения с законодательной, исполнительной и судебной ветвями единой государственной власти является весьма актуальными.

Автор резюмирует, что первооснову публичной власти составляют институты гражданского общества, которые входят в содержание понятия публичной власти и являются в нем коренными.

Ключевые слова: поправки к Конституции Российской Федерации, государственная власть, публичная власть, институты гражданского общества.
$\mathrm{P}$ азвитие российской государственности очень интенсивно и динамично, хотя происходит в весьма напряженной обстановке как в мировом социуме, так и у нас в стране. Бушующая пандемия COVID-19 наложила свой отпечаток на нормальную жизнедеятельность как институтов гражданского общества, так и органов публичного администрирования. Однако эти и иные негативные обстоятельства не оказывают существенного влияния на дальнейший прогресс в развитии российской государственности.

В современной России достигла своего апогея административная реформа, перманентно проводимая уже не один десяток лет, включающая новые подходы к правовому регулирования контрольной и надзорной деятельности, реформирование законодательства об административной ответственности, которое впервые нашло свое выражение в принятии двух кодифицированных документах - материальном кодексе об административных правонарушениях и процессуальном кодексе, прописывающем порядок рассмотрения дел об административных правонарушениях.

Здесь уместно отметить, что особой вехой реформирования российской государственности стало принятие поправок к Конституции Российской Федерации (далее - Конституция РФ), инициированных Президентом России.

Обращаясь к заявленной проблематике уместно отметить, что Конституция РФ 1993 г. провозгласила в качестве приоритетных права и свободы человека и гражданина, а также за их защиту. Конституция стала существенной вехой в становление и развитие современной России, как правового, социального, демократического государства, деятельность которого в первую очередь направлена на защиту прав и свобод человека и гражданина, а также всего гражданского общества.

Основной закон закрепляет понятие государственной власти в нашей стране. Об этом гласят ст. ст. 3, 5, 10, 11 Основного закона. Упоминаются разные уровни государственной власти и в других статьях Конституции РФ.

До принятия поправок к Конституции РФ, в Основном законе страны имелись лишь указания на государственную власть и местное самоуправление т.е., власть, осуществляемую государством и муниципалитетом, соответственно. В тоже время, государственная власть в РФ подразделяется на федеральную и региональную:

- президент РФ

- Правительство РФ

- Федеральное Собрание РФ

- суды РФ на федеральном уровне;

- главы регионов

- правительства регионов

- парламенты регионов

- мировые судьи в регионах (субъектах Федерации) на местном уровне.

Особняком стоит местное самоуправление. В него 
входят:

- главы местного самоуправления

- муниципальные депутаты

- администрация (исполнительная власть).

Здесь следует обратиться к очень существенному фактору, который вытекает и подтверждает целесообразность исследуемой нами проблематики. Особо следует отметить, что после всенародного обсуждения и одобрения Конституционным Судом РФ вступили в силу поправки в Конституцию, прописанные в Законе Российской Федерации о поправке к Конституции Российской Федерации от 14 марта 2020 г. № 1-ФК3 «О совершенствовании регулирования отдельных вопросов организации и функционирования публичной власти» [2].

По мнению автора важнейшей новеллой, связанной с внесением законом о совершенствовании регулирования отдельных вопросов организации и функционирования публичной власти, стало отнесение к ведению Российской Федерации вопросов организации публичной власти. Легитимное звучание получил термин «публичная власть», существенно отличающийся по содержанию от термина «государственная власть».

Закрепление категории «публичная власть» в новой редакции Конституции представляется важным и своевременным шагом. При этом следует согласиться с позицией Конституционного Суда РФ о том, что «принцип единой системы публичной власти, хотя и не нашел буквального закрепления в главе 1 Конституции Российской Федерации, вместе с тем имплицитно следует из многих конституционных положений» [3]. Данная позиция доказывалась многими российскими правоведами с момента принятия Конституции и до сегодняшнего дня. Давно назрела необходимость закрепления в Конституции принципа единства системы публичной власти. Доктринально данный принцип формулировался и отстаивался в российской науке на протяжении довольного длительного периода времени.

В 1 главе ныне действующей Конституции Российской Федерации: «Основы конституционного строя «содержится достаточно положений, относящихся к публичной власти. Так, в соответствии со ст.3 Конституции Российской Федерации носителем суверенитета и единственным источником власти в Российской Федерации является ее многонациональный народ. Народ осуществляет свою власть непосредственно, а также через органы государственной власти и органы местного самоуправления. Высшим непосредственным выражением власти народа является референдум и свободные выборы.

Принцип разделения властей конституционно закреплен в ст. 10 Конституции Российской Федерации, в соответствии с которой государственная власть в Российской Федерации осуществляется на основе разделе- ния на законодательную, исполнительную и судебную. Органы законодательной, исполнительной и судебной власти самостоятельны.

Ст.11. Конституции Российской Федерации закрепляет положение о том, что государственная власть в Российской Федерации осуществляется Президентом Российской Федерации, Федеральным Собранием (Советом Федерации и Государственной Думой), Правительством Российской Федерации, судами Российской Федерации. Государственную власть в субъектах Российской Федерации осуществляют образуемые ими органы государственной власти в соответствии с разграничением предметов ведения и полномочий между органами государственной власти Российской Федерации и органами государственной власти субъектов Российской Федерации.

И, наконец, ст. 12 Конституции Российской Федерации признает и гарантирует местное самоуправление, которое в пределах своих полномочий является самостоятельным. Органы местного самоуправления не входят в систему органов государственной власти.

Анализируя все вышеназванные основы конституционного строя Российской Федерации следует заметить, что сама природа организации и осуществления публичной власти в Российской Федерации исходит из народного суверенитета, полновластия многонационального народа, его законных прав и интересов, выражается в разнообразных формах осуществления народом своей власти в стране. Соответственно, органы государственной власти, в лице Президента Российской Федерации, Федерального Собрания Российской Федерации, Правительства Российской Федерации, региональных законодательных, исполнительных органов, а также вооруженных сил Российской Федерации, правоохранительных и иных органов государственной власти всех уровней, а также органы местного самоуправления призваны служить интересам многонационального народа России.

Такое служение интересам многонационального народа Российской Федерации должно выражаться, прежде всего, в принятии органами государственной власти нормативно-правовых актов и проведении внутренней политики, направленной на защиту интересов российских граждан, защиту их конституционных прав, свобод и законных интересов. Иными словами, публичная власть должна выступать политическим гарантом защиты интересов российских граждан и гражданского общества в целом.

Вышеизложенное представляется целесообразным аргументировать следующими положениями. В своем Послании Федеральному Собранию от 15.01.2020 года [15] Президент Российской Федерации В. Путин предложил закрепить принципы единой системы власти: «Счи- 
таю необходимым закрепить в конституции принципы единой системы публичной власти. Выстроить эффективное взаимодействие между государственными и муниципальными органами. Полномочия и реальные возможности местного самоуправления, самого близкого к людям уровня власти, могут и должны быть расширены и укреплены, при этом обратив внимание на нынешний разрыв между государственным и муниципальным уровнями власти, подчеркнув, что такая «запутанность полномочий» отрицательно сказывается на людях, приводит к проблемам в образовании, здравоохранении и в других сферах. «Предусмотренные законодательством общие для всех граждан права, возможности и гарантии в разных регионах и муниципалитетах обеспечиваются по-разному», - сказал президент, отметив, что это несправедливо по отношению к человеку, а также несет прямую угрозу российском обществу и целостности страны. По мнению В. Путина решение проблемы разрыва между государственным и муниципальным уровнями управления требует закрепления в Конституции РФ принципов единой системы публичной власти [16].

Положения о единстве публичной власти создают потенциал для ее эффективной организации и осуществления на всех уровнях (федеральном, региональном, муниципальном) в интересах граждан. Организация публичной власти справедливо отнесена к ведению РФ (п. «Г» Ст. 71 Конституции).

О единстве системы публичной власти и взаимодействии входящих в нее органов указано в ч. 2 ст. 80 Основного Закона, а также ч. 3 ст. 132 Конституции - органы местного самоуправления и органы государственной власти входят в единую систему публичной власти в Российской Федерации.

Профессор Чиркин В.Е. отмечал, что «Государственная власть, как власть социальная, является не частной, как это имеет место в семье, не корпоративной, как в организации, а публичной. Это - власть, действующая от имени всего общества» [12].

Как нами отмечалось ранее, понятие «публичная власть» объединяет в себе «федеральную», «региональную» и «местную (муниципальную)» власти. Дело в том, что зачастую власти регионов называют государственными, однако, это не совсем верно. Россия действительно, осуществляет свою власть через власти региональные. Именно РФ образует власти «на местах». Образованные таким образом, власти сами организуют свои властные органы. При этом, субъекты вправе самостоятельно решать, как им и что организовывать внутри. Но, регион в любом случае является частью федерации, не образуя отдельное государство. Под государством же нужно понимать исключительно Федерацию.

Примерно та же картина существует и в отношении муниципальных властей. Говоря о муниципальных властях, многие граждане понимают государство, однако, это тоже не верно. Органы местного самоуправления не входят в систему государственной власти в РФ, исходя из ст. 12 Конституции. Это вызывает и путаницу не только на словах, но и в документах.

Дабы устранить эти разночтения, вводится новое понятие. Оно даст всем трем уровням власти в России единое определение - публичная власть. Таким образом органы местного самоуправления и органы государственной власти входят в единую систему публичной власти в Российской Федерации и осуществляют взаимодействие для наиболее эффективного решения задач в интересах населения, проживающего на соответствующей территории. Смысл здесь заключается в том, что сверху донизу все элементы власти должны работать слажено и в интересах народа.

Как справедливо отмечает профессор А. Чертков «потенциал Конституции был далеко не исчерпан, некоторые конституционные поправки важны для развития России. Прежде всего давно назрела необходимость закрепления в Конституции принципа единства системы публичной власти. Доктринально данный принцип формулировался и отстаивался в российской науке, обретение им конституционного закрепления можно только приветствовать» [13].

В развитие данного положения представляется целесообразным сделать некоторые умозаключения. Как нами отмечалось ранее, понятие «публичная власть» объединяет в себе органическую триаду: «федеральную», «региональную» и «местную (муниципальную)» власти. О единстве системы публичной власти и взаимодействии входящих в нее органов указано в ч. 2 ст. 80 Основного Закона, а также ч. 3 ст. 132 Конституции - органы местного самоуправления и органы государственной власти входят в единую систему публичной власти в Российской Федерации. Однако здесь уместно отметить, что при обращении к ст. 2, 3 Конституции усматривается, что человек, его права и свободы являются высшей ценностью. Признание, соблюдение и защита прав и свобод человека и гражданина - обязанность государства. При этом носителем суверенитета и единственным источником власти в Российской Федерации является ее многонациональный народ. Народ осуществляет свою власть непосредственно, а также через органы государственной власти и органы местного самоуправления.

На основе вышеизложенного, представляется целесообразным констатировать, что систему публичной власти составляют федеральные органы государственной власти, органы государственной власти субъектов федерации, а также органы местного самоуправления в их совокупности, осуществляющие в конституционно установленных приделах на основе принципов согласо- 
ванного функционирования в соответствии законодательством вопросы организационно-правового, функционального и финансово-бюджетного взаимодействия, в том числе по вопросам передачи полномочий между уровнями публичной власти, свою деятельность в целях соблюдения и защиты прав и свобод человека и гражданина, создания условий для социально экономического развития страны, при этом основополагающим фундаментом публичной власти является именно народовластие. При таком подходе институты гражданского общества входят в содержание понятия публичной власти и являются в нем коренными (основополагающими).

В развитие вышеизложенной аргументации также уместно отметить, что существенной новацией Конституции стало наделение Правительства РФ в п. «е» ст.114 компетенцией по осуществлению мер по обеспечению законности, прав и свобод граждан, охране собственности и общественного порядка, борьбе с преступностью [2], при этом в шести ее пунктах расписываются конкретные полномочия:

е.1) осуществляет меры по поддержке институтов гражданского общества, в том числе некоммерческих организаций, обеспечивает их участие в выработке и проведении государственной политики;

е.2) осуществляет меры по поддержке добровольческой (волонтерской) деятельности;

е.3) содействует развитию предпринимательства и частной инициативы;

е.4) обеспечивает реализацию принципов социального партнерства в сфере регулирования трудовых и иных непосредственно связанных с ними отношений;

е.5) осуществляет меры, направленные на создание благоприятных условий жизнедеятельности населения, снижение негативного воздействия хозяйственной и иной деятельности на окружающую среду, сохранение уникального природного и биологического многообразия страны, формирование в обществе ответственного отношения к животным;

е.6) создает условия для развития системы экологического образования граждан, воспитания экологической культуры [17];

На наш взгляд добровольцы (волонтеры) и некоммерческие организации - это авангард гражданского общества и поправки к Конституции РФ только укрепили их правовое положение. Волонтерские движения за последние годы все больше и больше участвуют в жизни страны и это показывает изменение в мировоззрении наших сограждан в сторону большего сострадания и сочувствия друг к другу. Желание протянуть руку помощи, подставить плечо особенно важно в той ситуации, в которой страна, да и все мировое сообщество оказалась в борьбе с пандемией коронавируса COVID-19.

Руководство страны понимает, что волонтеры в России делают чрезвычайно важное дело, очень многие вещи было бы невозможно сделать без их жертвенного добровольческого труда. Сегодня, когда весь мировой социум столкнулись с бедой мирового масштаба, волонтеры по всей стране проявляют истинный героизм, развозят продукты и лекарства пожилым и многодетным семьям, готовят еду для престарелых и др. Их роль огромна, и важно подчеркнуть это законодательно прописано в Основном законе страны.

Согласно опросам ВЦИОМ, более 90\% граждан на вопрос «Кому вы доверяете?» выбирали ответ «Добровольцам». Неслучайно только в 2019 г. в различных волонтерских проектах приняли участие 15 млн человек - 10-я часть населения России. «С каждым годом доверие к некоммерческим, общественным организациям растет, и почти не осталось отраслей и больших проектов, где бы ни принимали участие добровольцы», справедливо отметил на международном форуме добровольцев первый заместитель главы Администрации Президента РФ Сергей Кириенко [14].

Здесь уместно отметить, что поправки к Конституции России были приняты на общероссийском голосовании и утверждены Законом РФ «О поправках к Конституции РФ», от 11 марта 2020 г. В статье 3 пункта 4 которого прописано, что «Статья 1 настоящего Закона вступает в силу со дня официального опубликования результатов общероссийского голосования (с учетом особенностей, установленных частью 7 настоящей статьи) в случае, если предусмотренные ею изменения в Конституцию Российской Федерации получили одобрение в ходе общероссийского голосования [2]. Представляется данные положения закона также являются аргументацией выдвинутых нами умозаключений.

Резюмируя вышеизложенное, представляется целесообразным сделать некоторые умозаключения.

Современная Россия - правовое, социальное, демократическое государство, в котором интересы человека и гражданина являются приоритетными. В пользу этих положений свидетельствуют поправки к Конституции, принятые на всенародном обсуждении в 2020 г. На основе их анализа, по мнению автора, публичная власть не стоит ограничивать только «федеральной», «региональной» и «местной (муниципальной)» властью, следующих из вышеперечисленных положений Конституции РФ. Основополагающим фундаментом публичной власти является именно народовластие, при этом институты гражданского общества входят в содержание понятия публичной власти и являются в нем коренными. 


\section{ЛИТЕРАТУРА}

1. Конституция Российской Федерации.

2. Закон Российской Федерации о поправке к Конституции Российской Федерации от 14 марта 2020 г. № 1-ФКЗ «0 совершенствовании регулирования отдельных вопросов организации и функционирования публичной власти» // Собрание законодательства Российской Федерации. - 2020. - № 11. - Ст. 1416.

3. Заключение Конституционного суда РФ от 16 марта 2020. № 1-3 М «0 соответствии положениям глав 1, 2 и 9 Конституции Российской Федерации не вступивших в силу положений Закона Российской Федерации о поправке к Конституции Российской Федерации «0 совершенствовании регулирования отдельных вопросов организации и функционирования публичной власти», а также о соответствии Конституции Российской Федерации порядка вступления в силу статьи 1 данного Закона в связи с запросом Президента Российской Федерации. Санкт-Петербург 16 марта 2020 года

4. Федеральный закон от 27 июля 2010 года № 210-Ф3 «06 организации предоставления государственных и муниципальных услуг« // С3 РФ от 2 августа 2010 г. № 31 ст. 4179.

5. Федеральный закон от 06.10.1999 № 184-Ф3 (ред. от 29.07.2017) «0б общих принципах организации законодательных (представительных) и исполнительных органов государственной власти субъектов Российской Федерации» (в ред. Федерального закона от 29.03.2008 № 30-Ф3) // СЗ РФ. 2008. № 13. Ст. 1186.

6. Атаманчук Г.В. Теория государственного управления. М. 2004. С. 62, Административное право: Учебник /под ред. С.А. Старостина - М.: ИНФРА-М, 2010 448 с. Административное право и процесс: полный курс. - М.: Изд. Тихомирова М.Ю., 2005. - 697 с. Административное право России: курс лекций/ под ред. Н.Ю. Хаманевой. - М.: ТК Велби, Изд-во Проспект, 2008. - 704 с. Агапов А.Б. Административное право: Учеб для вузов - М.: Дашков, 2006. - 435 с.

7. Воронов А.М. Правовая доктрина современной России: проблемы и перспективы. Юридическая наука в Китае и России. 2018. №2. С. 45-48.

8. Воронов А.М. К вопросу правовой регламентации государственного администрирования // Административное право и процесс. 2018. № 4. С. 38-43.

9. Воронов А.М. Конституция Российской Федерации - отправная точка развития правовой доктрины Российской государственности. Международный журнал конституционного и государственного права . 2018. №4. С. 10-13.

10. Кононов П.И. О современных подходах к пониманию административного права: право публичного управления или право публичного благополучия // Административное право и процесс. 2017. № 3. С. 69.

11. Редкоус В.М. О новом этапе административной реформы в Российской Федерации // материалы международной научно-практической конференции «Конституционализм и правовая политика: уникальность и секция. многообразие на национальном и международном уровнях», Байтурсыновские чтения. Кустанай 2020. С. 251.

12. Чиркин В.Е.-М. Государствоведение. 2000. С. 81.

13. Чертков А. Публичная власть в обновленной Конституции https://proza.ru/2020/02/12/1479

14. https://aif.ru/politics/constitutional_amendments/nado_podderzhat_volontyorov_popravki_v_konstituciyu_pomogut_tem_kto_sam_got

15. https://www.interfax.ru/chronicle/poslanie-prezidenta-federalnomu-sobraniyu-2020.htmlhttps://www.interfax.ru/chronicle/poslanie-prezidenta-federalnomusobraniyu-2020.html

16. http://www.consultant.ru/document/cons_doc_LAW_342959/

17. http://elibrary.ru/item.asp?id=43032451

(c) Воронов Алексей Михайлович (Alex_voronoff@mail.ru).

Журнал «Современная наука: актуальные проблемы теории и практики» 